\title{
An Empirical Research on Beximco Knitting Ltd: Ratio, DuPont, Valuation and Pro-Forma Analysis
}

\author{
K. M. Anwarul Islam ${ }^{1}$
}

${ }^{1}$ Department of Business Administration, The Millennium University, Dhaka, Bangladesh

Correspondence: C/O K. M. Kamal Uddin, Deputy Registrar, Registrar's office, Room No-201(K),Dhaka University, Dhaka-1000, Tel: +8801768343171, E-mail:ai419bankingdu@gmail.com

Received: June 21, 2017

Accepted: July 05, 2017

Online Published: July 17, 2017

\begin{abstract}
Beximco Knitting Ltd belongs to the Textile Industry. This paper examines some ratio analysis that showed the overall internal liquidity position of the company, that is not satisfactory; because of the entire ratio performance is not good, operating efficiency ratio is not good, indicates that lower efficiency generate capacity in terms of sale, debt-equity ratio is increasing overtime in order to employ the more debt financing as long-term borrowing compare to the equity financing, which make the firm more risky. Beximco Knitting Ltd is more sensitive to leverage compare to net profit margin and Asset turnover Discounted Cash Flow Analysis Model is using for valuation of the Beximco Knitting Ltd's prospective analysis. Forecasting the cash flow we have to use 2016-2017 as the base year of foresting cash flow for 2018-2020.The terminal growth rate of free cash flow is $2 \%$ and the present value of free cash flow is arrived using the 'Exit Multiple' model.Free cash flow to equity is discounted $10.77 \%$ to arrive at an estimated present value of free cash flows available to equity (debt and equity holders as a group), which is also known as Enterprise Value. Equity value per share (142.07) on the other hand, the market price of Beximco Knitting is 47.5 tk per share, which indicates the share price is undervalued. Under pro-forma analysis we find out that all items of the financial statement is improving based on the assumption, but as investor's perspective we think investing in that company is not beneficial over the long run.Because the company can't earn positive return until 2020. Findings of the artcle are to really negative signs in accordance the investor's perspective, because its earnings per share are not attractive as much to invest.
\end{abstract}

Keywords: Beximco Knitting Ltd, Ratio, DuPont, Valuation, Pro-Forma.

\section{Introduction}

In the area of equity analysis, research in finance has not been successful. Equity analysis or fundamental analysis - was once the mainstream of finance. But, while enormous steps have been taken in pricing derivatives on the equity, techniques to value equities have not advanced much beyond applying the dividend discount model. So-called asset pricing models, like the Capital Asset Pricing Model, have been developed, but these are models of risk and the expected return, not models that instruct how to value equities. Real option analysis has been applied to equity valuation, but the measurement problems are significant. Some progress has been made by accounting researchers in what has come to be referredto as accounting-based valuation research. That is not 
K. M. Anwarul Islam surprising. Equity analysis is largely an analysis of information, and accountants deal with information about firms. This paper carries the recent research to the level of product design. Not only are relevant ratios identified, but an algebra like the traditional DuPont analysis (which is incorporated here) - ties the ratios together in a structured way. This algebra not only explains how ratios "sum up" as building blocks of residual income but also establishes a hierarchy so that many ratios are identified as finer information about others. So the analyst identifies certain ratios as primary and considers other ratios down the hierarchy only if they provide further information. This brings an element of parsimony to practical analysis. But it also provides a structure to researchers who wish to build (parsimonious) forecasting models and accounting-based valuation models.(Chu, N. C., Taylor, R. N., Chavagnac, V., Nesbitt, R. W., Boella, R. M., Milton, J. A., ... \& Burton, K. ,2002).

\section{Data Analysis}

\subsection{Ratio Analysis}

The internal liquidity (solvency) ratio, which measure the ability to meet future short-term financial obligations,

\subsubsection{Performance of Current Ratio}

\begin{tabular}{lcccc}
\hline Year & 2012 & 2013 & 2014 & 2015 \\
\hline Current ratio & 3.16 & .88 & 1.00 & .96 \\
\hline
\end{tabular}

In this table we can see that current ratio is decrease in year 2013 \& 2015 and increase in year 2012 \& 2014. Because of increasing total current asset in year 2012 \& 2014 by increasing the marketable securities \& inventories and decreasing the current liabilities in year 2012 \& 2014 by decrease the A/P and increasing the liabilities in year 2013 and 2015 by increase of A/P \& notes payable. Which indicate Beximco Knitting has lower ability to pay the shot -term obligation against of current asset?

\subsubsection{Performance of Quick Ratio}

\begin{tabular}{lllll}
\hline Year & 2012 & 2013 & 2014 & 2015 \\
\hline Quick ratio & 0.91 & 0.27 & 0.52 & 0.48 \\
\hline
\end{tabular}

Quick ratio is decrease in year 2013 \& 2015 and increase in year 2012 \& 2014. Because of increasing numerator by increase in A/R \& marketable securities in year 2012 \& 2014 and decreasing the current liabilities in year 2012 \& 2014 by decrease the A/P. According to increase numerator as much compare to decrease denominator, which increase the quick ratio and vice-versa the rest of the year.

2.1.3 Performance of Turnover Ratio

\begin{tabular}{lllll}
\hline Year & 2012 & 2013 & 2014 & 2015 \\
\hline Inventory turnover & 1.20 & 0.62 & 0.79 & 0.78 \\
\hline
\end{tabular}

Inventory turnover ratio decrease in 2013 and 2015, because of decreasing the COGS \& increase the average inventories. Inventory turnover ratio increase in 2012 and 2014, because of increasing the COGS \& decrease the average inventories.

The current ratio, quick ratio, inventory turnover ratio is changing over time that means not stable over the year. Company's overall internal liquidity position is not satisfactory; because of the entire ratio performance is not good.

Evaluate the operating performance, which measure the operating efficiency and operating profitability. 


\subsubsection{Operating Efficiency Ratio}

2.1.4.1 Fixed Asset Turnover Ratio

\begin{tabular}{lllll}
\hline Year & 2012 & 2013 & 2014 & 2015 \\
\hline $\begin{array}{l}\text { Fixed } \\
\text { turnover ratio }\end{array}$ & 1.20 & 0.62 & 0.79 & 0.78 \\
\hline
\end{tabular}

Fixed asset turnover decrease only in year 2013 because of decreasing the sales revenue in year 2013 but increase Fixed asset turnover the rest of the years because of decreasing the average net fixed asset, which indicate the less efficiently usage of the fixed asset.

\subsubsection{Total Asset Turnover Ratio}

\begin{tabular}{lllll}
\hline Year & 2012 & 2013 & 2014 & 2015 \\
\hline Total asset turnover ratio & 0.50 & 0.29 & 0.29 & 0.32 \\
\hline
\end{tabular}

Total asset turnover ratio decrease in year 2013 and increase in year 2015 in order to

Decrease the sales revenue but increase the total net asset in year 2013. In year 2015 the total net asset increases as a result of increasing the total asset turnover ratio.

Fixed asset turnover and total asset turnover ratio is not satisfactory because it's not stable, that means the overall operating efficiency ratio is not good, indicates that lower efficiency generate capacity in terms of sale.

\subsubsection{Operating Profitability Ratio}

\subsubsection{Gross Profit Margin Ratio}

\begin{tabular}{lllll}
\hline Year & 2012 & 2013 & 2014 & 2015 \\
\hline Gross profit margin & 4.76 & 4.80 & 3.59 & 9.20 \\
\hline
\end{tabular}

This ratio measure the rate of profit on sales, Beximco Ltd Gross profit margin ratio is increase in year 2013 and 2015; according to decrease the COGS compare to the sales revenue. Which indicate the company's non-efficient ability of production process because of not keeping the stability of performance?

\subsubsection{Net Profit Margin Ratio}

\begin{tabular}{lllll}
\hline Year & 2012 & 2013 & 2014 & 2015 \\
\hline Net profit margin & -13.82 & -32.27 & -22.58 & -13.77 \\
\hline
\end{tabular}

Net profit margin decrease more in year 2013, in order to face the most losses because of gross profit doesn't cover the total operating expenses, that improving the last two-year because of increasing the sales revenue.

\subsubsection{Operating Profit Margin}

\begin{tabular}{lllll}
\hline Year & 2012 & 2013 & 2014 & 2015 \\
\hline Operating profit margin & 0.23 & -4.71 & -2.53 & 4.51 \\
\hline
\end{tabular}


K. M. Anwarul Islam

Operating profit margin ratio decrease in year 2013 in order to face the most operating losses because of increasing the operating cost and improve the ratio last two-year because of increasing the sales revenue, which cover the operating losses.

\subsubsection{Return on Total Asset Ratio}

\begin{tabular}{lllll}
\hline Year & 2012 & 2013 & 2014 & 2015 \\
\hline Return on total asset & -6.87 & -9.30 & -6.61 & -4.47 \\
\hline
\end{tabular}

Return on total asset ratio decrease in year 2013 in order to face the most income losses because of increasing the interest expense and improve the ratio last two-year, because of minimize the income losses which adjust the non stability of the total asset utilization.

\subsubsection{Return on Equity Ratio}

\begin{tabular}{lllll}
\hline Year & 2012 & 2013 & 2014 & 2015 \\
\hline Return on equity ratio & -24.80 & -65.06 & -137.60 & -597.49 \\
\hline
\end{tabular}

Return on equity ratio is decreasing over the year because of increasing the financial leverage employed in the firm, which makes the firm more risky, and decline the return on equity capital.

Analysis all the ratio it is clear that Beximco ltd faces worst position in year 2003, the last two-year firm trying to minimize the losses. That's why we can say the Operating profitability is not satisfactory.

\subsubsection{Debt-Equity Ratio}

\begin{tabular}{lcccc}
\hline Year & 2012 & 2013 & 2014 & 2015 \\
\hline Debt-equity ratio & .14 & .18 & 4.32 & 28.75 \\
\hline
\end{tabular}

Debt-equity ratio is increasing overtime in order to employ the more debt financing as long -term borrowing compare to the equity financing, which make the firm more risky.

\subsubsection{Debt Ratio}

\begin{tabular}{lcccc}
\hline Year & 2012 & 2013 & 2014 & 2015 \\
\hline Debt ratio & 0.21 & 0.86 & 0.95 & 0.99 \\
\hline
\end{tabular}

Debt ratio is increasing overtime in order to employ the increasing amount of long term debt and borrowing.

\subsubsection{Sensitivity Analysis of ROE}

Beximco Knitting Ltd is more sensitive to leverage compare to net profit margin and Asset turnover. If company employs leverage more the ROE would increase more, compare to other two factors.

\begin{tabular}{ll}
\hline Items of Sensitivity & Average \% Change \\
\hline Asset turnover & $-4.64 \%$ \\
\hline Net profit margin & $6.36 \%$ \\
\hline Leverage & $378.76 \%$ \\
\hline
\end{tabular}


2.2 DuPont Analysis

\begin{tabular}{|c|c|c|c|c|}
\hline DuPont Analysis & 2012 & 2013 & 2014 & 2015 \\
\hline Net Profit AT/Sales & $-13.82 \%$ & $-32.27 \%$ & $-22.58 \%$ & $-13.77 \%$ \\
\hline Sales/Total Assets & $49.68 \%$ & $28.81 \%$ & $29.27 \%$ & $32.47 \%$ \\
\hline $\mathrm{ROA}$ & $-6.87 \%$ & $-9.30 \%$ & $-6.61 \%$ & $-4.47 \%$ \\
\hline Net Profit AT/Total Assets & $-6.87 \%$ & $-9.30 \%$ & $-6.61 \%$ & $-4.47 \%$ \\
\hline $\begin{array}{l}\text { Total Assets/Stockholders. } \\
\text { Equity }\end{array}$ & $361.10 \%$ & $699.74 \%$ & $2081.79 \%$ & $13360.58 \%$ \\
\hline ROE & $-24.80 \%$ & $-65.06 \%$ & $-137.60 \%$ & $-597.49 \%$ \\
\hline
\end{tabular}

In the DuPont analysis ROA is calculated by the total operating margin into total asset turnover, which is decrease in year 2013, because of decreasing the total operating margin. The multiplied total asset turnover and financial leverage multiplier calculate ROE, which is decreasing over the year because of increasing the financial leverage employed in the firm.

\subsection{Valuation of Beximco Knitting Ltd}

There are number of model are available to estimate the value of target firm, because valuation is the process of converting a forecast into an estimate of the value of the firm or some component of the firm. We are using the Discounted Cash Flow Analysis Model for valuation of the Beximco Knitting Ltd's prospective analysis. Under this approach the production of detailed, multiple-year forecast of cash flow. Forecasting the cash flow I have to use 2016-2017 as the base year of foresting cash flow for 2018-2020.

\subsubsection{The Discounted Cash Flow Analysis Model for Valuation Therefore Involves the Following Steps}

\section{Setp-1: Forecasts Free Cash Flow Available To Equity Holders (Or To Debt And Equity Holders) Over} Finite Forecast Horizons 4 Years.

To forecasts free cash flow available to equity holders we have to calculate the growth rate of the sales revenue, COGS average the revenue and COGS. Find out the operating cash flow in adjust the general and administrative $\%$ of sales as $15 \%$. Doing so we finding out the operating cash flow for Beximco of initial and forecasted year. Now EBIT was adjusted with depreciation /amortization and applying 30\% tax we must get the unleveled net income, which is again adjusted with change in working capital, capital expenditure and depreciation /amortization that come out net cash flow before debt.

\section{Step-2: Forecast Free Cash Flows Beyond The Terminal Year Based On Some Simplifying Assumption.}

Terminal values estimates for the abnormal earnings and ROE methods tend to represent a much smaller fraction of total value than under the discounted cash flow methods. To calculate the terminal values we make one assumption"Beximco Knitting Ltd doesn't grow up to 2020.The terminal growth rate of free cash flow is $2 \%$. The presents value of normal earnings is already reflected only the original book value of growth in book value over horizon. So the valuation formula would be the 'Exit Multiple' of free cash flow.

\section{Step-3: Discount Free Cash Flows To Equity Holders (Debt Plus Equity Holders) At The Cost Of Equity (Weighted Average Cost Of Capital), Which Is Available To Equity (Debt And Equity Holders As A Group)}

Finally, net cash flow from debt owner is issues of the new debt less retirements less the after -tax cost of interest. Free cash flow to equity is the combination change in book value of net asset (including change in working capital plus capital expenditure less depreciation expenses), change in book value of net deb. The forecasts are then discounted at the Beximco knitting Ltd's estimated cost of capital $(10.77 \%$ adjusted tax 
K. M. Anwarul Islam

advantage) to arrive at an estimated present value of free cash flows available to equity (debt and equity holders as a group), which is also known as Enterprise Value that is adjusted with cash and interest debt to find out the Equity Value, which is available for equity holder, if we divide this amount by the out standing share of the company then we get the Equity value per share (142.07).on the other hand, the market price of Beximco Knitting is 47.5 tk per share, which indicates the share price is undervalued.

2.3.2 For Pro- Forma Analysis for Prospective Analysis of the Individual Company, Therefore Involves the Following Steps

\section{Step-1: Prepare A Common Size Financial Statements (I/S, B/S)}

To prepare a common size balance sheet we have to calculate the all the items of balance sheet and income statement are converted based on the percentage of sales figure. The common size balance sheet and income statement was calculated at first individually based on the company's actual data. After converting the items of balance sheet and income statement based on the percentage of sales figure, we have to calculate the mean of the base year's item. And based on the mean we was forecast the next pro-forma of balance sheet and income statement as consolidated form.

\section{Step-2: Calculate Some Financial Ratio}

Under this step we have calculate the some ratio those are operating profit margin ratio, total asset turnover ratio, financial leverage multiplier and at last tax retention rate. After analysis the ratio result we found that Beximco Ltd's ROE was unstable in the base year (2016-2017) but pro-forma year (2018-2020) ROE was positive but declining year by year. Because of losing company it has not paying any tax and there is not dividend payment, as a result the company's sustainable growth will be the equal to the EOE for the pro-forma year.

\section{Step-3: Make Some Assumption}

Assumption is taken based on the company's current financial position and future prospect of the company.

\begin{tabular}{ll}
\hline No. & Assumption \\
\hline 1 & Sales growth 5\%, compound sales growth rate \\
\hline 2 & Other current account would be consistent with sales \\
\hline 4 & The estimated inventory would change by $5 \%$ of average sales growth in every year. \\
\hline 5 & Planned investment 5000000 in year 2016, next two year there is no need for additional \\
& investment, because the year 2017,2018 the investing amount would trying to come out. \\
& This additional investment is using purchasing the machinery that will be depreciated by \\
& Company would require additional financing in next year from debt financing and last \\
& risky by using debt financing. In year the borrowing at $14 \%$ will finance 2018.
\end{tabular}

\section{Step-4: Prepare The Pro-Forma, Financial Statement}

To calculate the pro-forma financial statement we have to at first meet up the previous steps. Based on the previous steps at first calculate the actual financial statement and based on the statement and other step we found the pro-forma statement. After analysis the pro-forma statement, its depicts that the income over the 2016 to 2020 its improving but not cover the losses position and not enjoying the positive income.

The all other items of the financial statement is improving based on the assumption, but as investors perspective 
An Empirical Research on Beximco Knitting Ltd: Ratio, DuPont, Valuation and Pro-Forma Analysis

we think investing in that company is not beneficial over the long run. Because the company can't earn positive return until 2020. Its really negative signs in accordance the investor's perspective, because its earnings per share are not attractive as much to invest.

Reference

Chu, N. C., Taylor, R. N., Chavagnac, V., Nesbitt, R. W., Boella, R. M., Milton, J. A., ... \& Burton, K. (2002). Hf isotope ratio analysis using multi-collector inductively coupled plasma mass spectrometry: an evaluation of isobaric interference corrections. Journal of Analytical Atomic Spectrometry, 17(12), 1567-1574.

Copyrights

Copyright for this article is retained by the author(s), with first publication rights granted to the journal. 